\title{
"Metode Pembelajaran Bahasa Arab di Madrasah Aliyah Negeri Program Keagamaan (MANPK) MAN 3 Makassar"
}

\author{
Andi Syarifah Witraniyah Assagaf ${ }^{1}$
}

\begin{abstract}
Abstrak
Penelitian ini bertujuan untuk mengetahui metode pembelajaran bahasa Arab yang digunakan di Madrasah Aliyah Negri program keagamaan (MANPK) MAN 3 Makassar, sebagai madrasah yang menerapkan sistem boarding school, MANPK MAN 3 Makassar melakukan berbagai upaya guna meningkatkan kualitas output dari peserta didiknya untuk mencapai visi dan misi dari madrasah yaitu menjadi madrasah keagamaan terdepan yang menjadi rujukan di Indonesia bagian timur yang unggul dalam ilmu-ilmu keislaman, bahasa dan karakter islami yang berorientasi timur tengah, MANPK MAN 3 Makassar telah berhasil mengirim siswa dan siswinya ke berbagai universitas baik di dalam maupun di luar negri seperti maroko dan mesir.
\end{abstract}

Kata kunci: Pembelajaran, Metode Pembelajaran Bahasa Arab

\section{LATAR BELAKANG}

Pendidikan merupakan proses menjadikan manusia mengenal potensi dirinya baik potensi jasmani, intelektual dan spiritual, sehingga menjadi warga negara yang baik melalui proses pembelajaran, dilakukan secara sadar dan terencana. Hal ini sesuai dengan Undang-undang nomor 20 tahun 2003 tentang Sistem Pendidikan Nasional, bahwa pendidikan adalah usaha sadar dan terencana mewujudkan suasana belajar dan proses pembelajaran agar peserta didik secara aktif mengembangkan potensi dirinya, untuk memiliki kekuatan spiritual keagamaan, pengendalian diri, kepribadian, kecerdasan, akhlak mulia, serta keterampilan yang diperlukan dirinya, masyarakat, bangsa dan negara. ${ }^{1}$

Pendidikan yang diyakini sebagai salah satu upaya peningkatan kualitas hidup manusia tersebut pada intinya bertujuan untuk memanusiakan manusia, mendewasakan, mengubah perilaku sehingga menjadi lebih baik. Pada kenyataannya pendidikan bukanlah persoalan sederhana melainkan sebuah sistem yang didalamnya mengandung elemen-elemen yang beragam dan saling berkaitan. Pendidikan merupakan kegiatan yang dinamis dan penuh tantangan. Itulah sebabnya, pendidikan senantiasa memerlukan perbaikan. Peran serta berbagai pihak sangat diharapkan dalam upaya perbaikan pendidikan. Keluarga, masyarakat dan sekolah merupakan tripusat pendidikan. ${ }^{2}$

Indonesia sebagai Negara dengan mayoritas penduduknya beragama Islam, tentu mengharapkan pendidikan yang dapat menopang kebutuhan rohani anak-anak. Oleh sebab itu pendidikan islam dirancang sedemikian rupa untuk menunjang kebutuhan masyarakat. Berbicara mengenai pendidikan Islam, tentu tidak terlepas dari bahasa Arab. Sebagai bahasa al-Qur'an dan hadis yang merupakan sumber utama agama Islam, tentu bahasa Arab menjadi salah satu bahasa yang harus dikuasai atau paling tidak dimengerti oleh umat Islam. Sebagaimana ditegaskan dalam QS Yūsuf/12: 2 


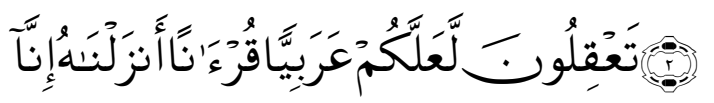

Terjemahnya:

“Sesungguhnya Kami menurunkannya berupa al-Qur'an dengan berbahasa Arab, agar kamu memahaminya"3

MANPK MAN 3 Makassar merupakan salah satu madrasah yang sangat memperhatikan pembelajaran bahasa Arab bagi siswa-siswinya. Madrasah ini dinilai berhasil dalam mendidik siswa-siswi khususnya dibidang bahasa Arab, hal ini dibuktikan dengan banyaknya siswa yang melanjutkan studi di luar daerah dengan mendapatkan beasiswa dari kampus yang dituju, bahkan dalam 6 tahun terakhir, madrasah ini berhasil mengantarkan 33 siswa-siswinya untuk melanjutkan studi di luar negeri, seperti: Mesir, Sudan, dan Madinah. ${ }^{4}$ Diantara upaya yang diusahakan sekolah guna merealisasikan visi dan misinya yaitu sekolah melakukan upaya-upaya yang maksimal seperti proses pembelajaran yang baik, sarana dan prasarana pembelajaran yang memadai, tenaga pengajar yang berkualitas, dan menerapkan metode pembelajaran yang tepat.

\section{PEMBELAJARAN}

Istilah pembelajaran berhubungan erat dengan pengertian belajar dan mengajar. Belajar, mengajar, dan pembelajaran. Belajar dapat terjadi tanpa peserta didik atau tanpa kegiatan mengajar formal lain. Sedangkan mengajar meliputi segala hal yang peserta didik lakukan di dalam kelas. Apa yang dilakukan peserta didik agar proses belajar mengajar berjalan lancar, bermoral dan membuat peserta didik merasa nyaman merupakan bagian dari aktifitas mengajar, juga secara khusus mencoba dan berusaha untuk mengimplementasikan kurikulum dalam kelas.

Pembelajaran menurut kamus besar bahasa Indonesia diidentikkan dengan kata "mengajar" yang berasal dari kata "ajar" yang berarti petunjuk yang diberikan kepada orang supaya diketahui (diturut) ditambah dengan awalan "pe" dan akhiran "an" menjadi pembelajaran yang berarti proses, perbuatan, cara mengajar atau mengajarkan sehingga anak didik mau belajar. Pembelajaran berdasarkan makna leksikal kamus berarti proses, cara, perbuatan mempelajari atau menjadikan orang belajar. ${ }^{5}$

Pembelajaran merupakan suatu proses interaksi antara guru dengan siswa, baik interaksi secara langsung seperti kegiatan tatap muka maupun secara tidak langsung, yakni dengan menggunakan berbagai media pembelajaran. ${ }^{6}$ Pendapat lain menyebutkan bahwa pembelajaran adalah suatu kegiatan yang berupaya membelajarkan siswa secara terintegrasi dengan memperhitungkan faktor-faktor lingkungan belajar, karakteristik siswa, karakteristik materi, serta berbagai strategi pembelajaran, baik penyampaian, pengelolaan, maupun pengorganisasian pembelajaran. ${ }^{7}$

Pembelajaran merupakan bantuan yang diberikan peserta didik agar dapat terjadi proses pemerolehan ilmu dan pengetahuan, penguasaan kemahiran dan tabiat, serta pembentukan sikap dan kepercayaan pada peserta didik. Dengan kata lain, pembelajaran adalah proses untuk membantu peserta didik agar dapat belajar dengan 
baik. ${ }^{8}$ Pembelajaran dapat diartikan sebagai suatu sistem atau proses membelajarkan subyek didik/pembelajar yang direncanakan peserta didik atau didesain, dilaksanakan peseta didik dan dievaluasi secara sistematis agar subyek didik/pembelajar dapat mencapai tujuan pembelajaran secara efektif dan efisien.

Pembelajaran dapat dipahami dari dua sudut pandang, yaitu: pertama, pembelajaran dipandang sebagai suatu sistem, pembelajaran terdiri dari sejumlah komponen yang terorganisasi antara lain tujuan pembelajaran, materi pembelajaran, strategi dan metode pembelajaran, media pembelajaran/alat peraga, pengorganisasian kelas, evaluasi pembelajaran dan tindak lanjut pembelajaran (remedial dan pengayaan). Pembelajaran sebagai suatu sistem pasti mempunyai tujuan yang dijadikan arah dalam kegiatan pembelajaran. Sistem berfungsi untuk merancang atau merencanakan suatu proses pembelajaran. "perencanaan adalah menentukan apa yang akan dilakukan. Perencanaan mengandung serangkaian-serangkaian keputusan yang luas dan penjelasanpenjelasan dari tujuan, penentuan kebijakan, penentuan program, penentuan metodemetode, dan prosedur tertentu dan penentuan kegiatan berdasarkan jadwal sehari-hari. ${ }^{9}$ Oleh karena itu, sistem merupakan proses untuk mencapai tujuan melalui pemberdayaan komponen pembelajaran. Apabila seluruh komponen bekerja sesuai dengan fungsinya, maka pastilah pembelajaran akan berlangsung secara dinamis dan mencapai tujuan yang telah ditetapkan.

Kedua, pembelajaran dipandang sebagai suatu proses, maka pembelajaran merupakan rangkaian upaya atau kegiatan guru dalam rangka membuat peserta didik berakhlak baik. Proses tersebut meliputi;

a. Persiapan, persiapan dimulai dengan merencanakan program pengajaran tahunan, semester, dan penyusunan persiapan mengajar. Juga penyiapan perangkat pembelajaran antara lain berupa; alat peraga dan alat evaluasi. Persiapan perencanaan pembelajaran mencakup kegiatan guru dengan menyiapkan materi ajar yang baik dan sempurna atau media cetak yang akan disampaikan dalam kegiatan pembelajaran. Bilamana seorang guru akan menggunakan perlengkapan mengajar, maka guru diperlukan untuk mengadakan pengecekan akan ketersediaan kelengkapan tersebut sehingga pembelajaran dapat berlangsung dengan baik.

b. Melaksanakan kegiatan pembelajaran dengan mengacu pada persiapan pembelajaran yang telah dibuat.

c. Menindaklanjuti pembelajaran yang telah dikelola. ${ }^{10}$

Pembelajaran adalah suatu kombinasi yang tersusun meliputi unsur-unsur manusiawi, material, fasilitas, perlengkapan, dan prosedur yang saling mempengaruhi mencapai tujuan pembelajaran. Manusia terlibat dalam sistem pengajaran terdiri dari siswa, guru, dan tenaga lainnya, misalnya tenaga laboratorium. Material, meliputi bukubuku, papan tulis, kapur, fotografi, slide dan film, audio dan video tape. Fasilitas dan perlengkapan, terdiri dari ruang kelas, perlengkapan audio visual, juga komputer. Prosedur, meliputi jadwal dan metode penyampaian informasi, praktik, belajar, ujian dan sebagainya. Rumusan tersebut tidak terbatas dalam ruang saja. Sistem pembelajaran dapat dilaksanakan dengan cara membaca buku, belajar di kelas atau di sekolah, karena diwarnai oleh organisasi dan interaksi antara berbagai komponen yang saling berkaitan, untuk membelajarkan peserta didik. ${ }^{11}$ 
Banyak ahli yang mengemukakan bahwa pembelajaran merupakan implementasi kurikulum, tapi banyak juga yang mengemukakan bahwa pembelajaran itu sendiri merupakan kurikulum sebagai aksi/kegiatan. Hakikat pembelajaran diantaranya adalah:

a. Kegiatan yang dimaksudkan untuk membelajarkan pebelajar

b. Program pembelajaran yang dirancang dan diimplementasikan sebagai suatu sistem

c. Kegiatan yang dimaksudkan untuk memberikan pengalaman belajar kepada pebelajar

d. Kegiatan yang mengarahkan pebelajar ke arah pencapaian tujuan pembelajaran

e. Kegiatan yang melibatkan komponen-komponen tujuan, isi pelajaran, sistem penyajian, dan sistem evaluasi dalam realisasinya.

Sejak turunnya wahyu pertama kepada Nabi Muhammad saw., Islam telah menekankan perintah untuk belajar. Pada ayat pertama Q.S al-'Alaq terdapat kata iqra' yang memiliki arti "membaca". Iqra' berasal dari akar kata yang berarti menghimpun. Dari menghimpun inilah lahir aneka makna seperti menyampaikan, menelaah, mendalami, meneliti, dan mengetahui ciri-ciri sesuatu, ${ }^{12}$ yang kesemuanya merupakan proses belajar manusia untuk mencapai berbagai macam kompetensi, kemahiran, dan sikap.

Dapat ditarik kesimpulan bahwa pembelajaran adalah usaha sadar dari guru untuk membuat siswa belajar, yaitu terjadinya perubahan tingkah laku pada diri siswa yang belajar, dimana perubahan itu dengan didapatkannya kemampuan baru yang berlaku dalam waktu yang relative lama dan karena adanya usaha.

\section{METODE PEMBELAJARAN BAHASA ARAB}

Pembelajaran bahasa Arab sampai saat ini masih menjadi fenomena dan problema. Problema tersebut termanifestasikan dalam beberapa hal yang banyak ditemukan dalam lembaga-lembaga pendidikan di negeri ini baik di sekolah umum, madrasah, pondok pesantren, maupun perguruan tinggi. Sejauh ini, belajar bahasa Arab masih kurang diminati masyarakat karena pada umumnya bahasa Arab tidak menggema dalam lingkungan kehidupan sehari-hari. Untuk itu, perlu adanya suasana yang dapat menumbuhkan minat dan motivasi siswa yang lebih mengenai belajar bahasa Arab. Oleh karena itu, dibutuhkan suatu metode dan media pembelajaran yang dapat menumbuhkan motivasi dan menarik minat, serta mengaktifkan semua siswa dalam proses belajar mengajar bahasa Arab. ${ }^{13}$ Karena ada perkataan yang sangat terkenal dalam pembelajaran yang berbunyi "al-tariqatu ahammu min al-mäddah" yang berarti metode itu lebih penting dari pada materi itu sendiri.

Ditinjau dari segi etimologis metode berasal dari bahasa Yunani yaitu methodos, kata ini terdiri dari dua suku kata, yaitu metha yang berarti melalui atau melewati, dan hodos yang berarti jalan atau cara. Maka metode memiliki arti suatu jalan yang dilalui untuk mencapai tujuan. Dalam bahasa Inggris dikenal term method dan way yang diterjemahkan dengan metode dan cara. Dalam bahasa Arab, kata metode diungkapkan dengan berbagai kata seperti al-tariqah, al-manhaj, dan al-wasīlah. Al-taríqah berarti jalan, al-manhaj berarti sistem, dan al-wasilah berarti mediator atau perantara. Dengan demikian, kata Arab yang paling dekat dengan arti metode adalah al-taríqah. ${ }^{14}$ 
Apabila ditinjau dari segi terminologis metode dapat dimaknai sebagai jalan yang ditempuh oleh seseorang supaya sampai pada tujuan tertentu, baik dalam lingkungan atau perniagaan, maupun dalam kaitan ilmu pengetahuan dan lainnya. Metode juga merupakan suatu cara yang dipergunakan untuk mencapai tujuan yang telah ditetapkan. Dalam kegiatan pembelajaran, metode sangat diperlukan oleh guru, dengan penggunaan yang bervariasi sesuai dengan tujuan yang ingin dicapai. Menguasai metode pembelajaran merupakan keniscayaan, sebab seorang guru tidak akan dapat mengajar dengan baik apabila ia tidak menguasai metode secara tepat.

Dalam pembelajaran bahasa Arab dikenal beberapa macam metode pembelajaran diantaranya adalah: tariquah al-Qawā'id wa al-Tarjamah, taríqahal-Mubāsyarah, tariqah al-Qirā'ah, tariqah al-Sam'iyyah al-Syafawiyyah, tariquah al-Tülifiyyah, dan lain-lain. Dewasa ini pembelajaran bahasa Arab, meskipun mengalami segudang masalah dalam pembelajarannya, namun pemerhati bahasa Arab dan guru-guru bahasa Arab pada lembaga pendidikan dan Madrasah telah ada yang melakukan berbagai inovasi dan kreasi dalam melaksanakan pembelajaran bahasa Arab, dengan menerapkan metodemetode pembelajaran mutakhir tersebut.

\section{Taríqah al-Qawā'id wa al-Tarjamah (Metode Kaidah dan Terjemahan)}

\section{a. Konsep dasar Tariqah al-Qawā'id wa al-Tarjamah}

Asumsi yang mendasari metode kaidah (tata bahasa Arab) dan terjemah adalah logika semesta yang menyatakan bahwa semua bahasa di dunia ini dasarnya sama, dan tata bahasa adalah cabang dari logika. ${ }^{15}$ Tata bahasa Arab secara etimologi adalah dasar, pedoman, asas, peraturan. ${ }^{16}$ Dapat juga diartikan rumusan asas-asas yang menjadi hukum. ${ }^{17}$ Di samping memiliki pengertian undang-undang baku yang dihimpun secara terikat.

Adapun tujuan pembelajaran tata bahasa Arab secara umum adalah "agar siswa dapat memahami dan memberi pemahaman terhadap lawan bicaranya tentang pembicaraan atau tulisan secara baik dan benar'. ${ }^{18}$ Dengan demikian, bukan berarti tata bahasa Arab itu sebagai tujuan langsung, akan tetapi hanya sebagai medium untuk mencapai tujuan yang dimaksud.

Ba'labaki menjelaskan bahwa dasar pokok metode ini adalah hapalan kaidah, analisa gramatika terhadap wacana, lalu diterjemahkan ke dalam bahasa yang digunakan sebagai pengantar pelajaran. ${ }^{19}$ Sedangkan perhatian terhadap kemampuan berbicara sangat kecil. Ini berarti bahwa titik tekan metode ini bukan melatih para pelajar agar pandai berkomunikasi secara aktif, melainkan memahami bahasa secara logis yang didasarkan kepada analisa cermat terhadap aspek kaidah tata bahasa. Tujuan metode ini menrut al-Naqah adalah agar para pelajar pandai dalam menghapal dan memahami tata bahasa, mengungkapkan ide-ide dengan menerjemahkan bahasa ibu atau bahasa kedua ke dalam bahasa asing yang dipelajari, dan membekali mereka agar mampu memahami teks bahasa asing dengan menerjemahkannya ke dalam bahasa sehari-hari atau sebaliknya. ${ }^{20}$ 
Berdasarkan pernyataan tersebut ada dua aspek penting dalam metode kaidah (tata bahasa) dan terjemah yaitu: pertama kemampuan menguasai kaidah dan bahasa; dan kedua, kemampuan menterjemahkan. Dari konsep dasar tersebut dapat dikemukakan bebrapa karakteristik metode kaidah dan terjemah yaitu:

1) Ada kegiatan disiplin mental dan pengembangan intelektual dalam belajar bahasa dengan banyak penghapalan, dan memahami fakta-fakta.

2) Ada penekanan pada kegiatan membaca, mengarang dan terjemahan, sedangkan kegiatan menyimak dan berbicara kurang diperhatikan.

3) Seleksi kosa kata khususnya berdasarkan teks-teks bacaan yang dipakai. Kosa kata ini diajarkan melalui daftar-daftar dwi bahasa, studi kamus dan penghafalan.

4) Unit yang mendasar ialah kalimat, maka perhatian lebih banyak dicurahkan kepada kalimat, sebab kebanyakan waktu para pelajar dihabiskan untuk aktifitas terjemah kalimat-kalimat terpisah.

5) Tata bahasa diajarkan secara deduktif, yaitu dengan menyajikan kaidahkaidah bahasa seperti dalam bahasa lain yang dianggap semesta. Ini kemudian dilatih lewat terjemahan-terjemahannya.

6) Bahasa pelajar sehari-hari (bahasa ibu atau bahasa kedua) digunakan sebagai bahasa pengantar.

2. Taríqah al-Mubāsyarah (Metode Langsung)

\section{a. Konsep Tarīqah al-Mubāsyarah}

Tariqah al-Mubāsyarah (metode langsung/direct method) adalah cara menyajikan materi pelajaran bahasa asing khususnya bahasa Arab dimana guru langsung menggunakan bahasa asing tersebut sebagai bahasa pengantar tanpa menggunakan bahasa anak didik sedikit pun dalam mengajar. Jika ada suatu kata-kata yang sulit dimengerti oleh anak didik, maka guru mengartikan dengan menggunakan alat peraga, mendemonstrasikan, menggambarkan dan lain-lain.

Yang menjadi konsep dari metode langsung (direct method) ini adalah karena siswa tidak dituntut agar dapat menghafal rumus-rumus tertentu, berpikir dan mengingat, maka dalam pengajaran bahasa, anak didik dilatih praktek langsung mengucapkan kata-kata atau kalimat tertentu. Sekalipun kata-kata atau kalimat tersebut masih asing dan tidak dipahami anak didik, namun sedikit demi sedikit kata-kata dan kalimat itu akan dapat diucapkan dan dapat pula mengartikannya. ${ }^{21}$

Dari konsep metode langsung di atas, dapat dikemukakan bahwa karekteristik atau ciri-ciri dari metode langsung adalah:

1) Berbahasa adalah berbicara, maka berbicara merupakan aspek yang harus dipriritaskan. Jika ada materi dalam bentuk bacaan, maka bacaan itu pertama kali disajikan dalam bentuk lisan. 
2) Sejak dini pelajar dibiasakan berpikir dalam bahasa bahasa asing yang dipelajari. Cara ini dilakukan agar pelajar pandai menggunakan bahasa secara otomatis layaknya bahasa ibu.

3) Bahasa ibu dan bahasa kedua atau terjemahan kedalam dua bahasa tersebut tidak digunakan.

4) Tidak begitu memperlihatkan tata bahasa, kalaupun ada hanya diberikan dengan mengulang-ulang contoh kalimat secara lisan, bukan dengan menjelaskan definisi atau menghapalkannya.

5) Ada asosiasi langsung antara kata-kata/ kalimat-kalimat dengan makna yang dimaksud melalui peragaan/demonstrasi, gerakan, mimik muka, gambar bahkan alam nyata. Atas dasar ini proses belajar dapat dilakukan baik di dalam maupun di luar kelas.

6) Untuk memantapkan pelajar dalam menguasai bahasa asing yang dipelajari, pengajar memberikan latihan berulang-ulang dengan contoh dan hapalan. ${ }^{22}$

\section{Taríqah al-Qirā'ah (Metode Membaca)}

\section{a. Konsep dan sejarah Tarīqah al-Qirä'ah}

Salah satu kegiatan penting untuk memperoleh informasi itu adalah membaca mulai dari membaca nyaring sampai pemahaman. Satuan bahasa yang terkecil adalah kosa kata, dan setiap makna kosa kata akan menentukan makna kalimat, makna kosa kata merupakan unsur yang sangat menentukan bahasa. Oleh sebab itu, kosa kata adalah salah satu komponen pengajaran bahasa yang paling penting. ${ }^{23}$

Dengan demikian dapat dikemukakan bahwa dasar metode membaca adalah penguasaan bahasa asing dengan memulainya dari penguasaan unsur bahasa terkecil, yaitu kosa kata yang didahului oleh latihan pengucapan yang benar, lalu pemahaman. Penguasaan unsur bahasa yang terkecil akan menentukan penguasaan bahasa secara keseluruhan, sedangkan pengucapan kata dan pelafalan kalimat yang baik dan benar merupakan modal dasar membaca yang baik dan benar. ${ }^{23}$

Adapun karakteristik metode ini adalah:

1) Tujuan utamanya adalah kemahiran membaca.

2) Materi pelajaran berupa buku bacaan dengan suplemen daftar kosa kata dan pertanyaan-pertanyaan isi bacaan, buku bacaan penunjang untuk perluasan, buku latihan mengarang dan percakapan.

3) Basis kegiatan pembelajaran adalah memahami isi bacaan, didahului pengenalan kosa kata pokok dan maknanya, kemudian mendiskusikan isi bacaan dengan bantuan guru.

4) Membaca diam (silent reading/qirāah șamitah) lebih diutamakan daripada membaca keras (loud reading/qirā'ah jahriyyah).

5) Kaidah bahasa diterangkan seperlunya tidak boleh berkepanjangan. ${ }^{24}$ 


\section{Tariqah al-Sam'iyyah al-Syafawiyyah (Metode Audio-Lingual)}

a. Konsep dan Sejarah Tariqah as-Sam'iyyah as-Syafawiyyah

Metode audiolingual adalah metode yang mendasarkan diri kepada pendekatan struktural dalam pengajaran bahasa. Sebagai implikasinya metode ini menekankan penelaahan dan pendeskripsian suatu bahasa yang akan dipelajari dengan memulainya dari sistem bunyi (fonologi), kemudian sistem pembentukan kata (morfologi), dan sistem pembentukan kalimat (sintaksis).

Pada dasarnya ada dua pendekatan teori yang mendasari pengajaran bahasa, sebagaimana kita ketahui, yaitu teori tata bahasa tradisional dan struktural. Keduanya memiliki pandangan yang saling berbeda dalam hal tata bahasa. Teori tradisional meyakini adanya tata bahasa yang semesta, sedangkan teori struktural meyakini bahwa struktur bahasa di dunia tidak sama, menurut teori tradisional bahasa yang baik dan benar adalah menurut para ahli bahasa (dalam istilah linguistik disebut presriptif), sedangkan menurut teori struktural yang baik dan benar adalah yang digunakan oleh penutur asli (dalam istilah linguitik disebut deskriptif). ${ }^{25}$

Adapun konsep metode audiolingual adalah sebagai berikut:

1) Dasar bahasa adalah percakapan, sedangkan tulisan adalah bagian dari percakapan. Maka materi yang perlu diprioritaskan dalam pengajaran bahasa asing atau bahasa tujuanadalah memahami pembicaraan dan berbicara, setelah itu baru aspek lain, yaitumembaca dan menulis.

2) Pembelajaran bahasa asing harus saling berhubungan satu sama lain seperti: istimā', kalām, qirā'ah dan kitābah, yaitu mendengarkan apa yang diucapkan oleh guru, kemudian mengucapkan apa yang diucapkan oleh guru, lalu membaca apa yang diucapkan oleh guru dan yang terakhir adalah menulis apa yang dibaca atau diucapkan oleh gurunya.

3) Materi yang harus dipelajari adalah bahasa asing atau bahasa tujuan, bukan materi mengenai bahasa. Artinya metode ini memiliki prinsip yang bertolak belakang dengan metode kaidah dan terjemah, yaitu tidak memperhatikan aspek kaidah bahasa maupun terjemahan, kecuali jika sangat terpaksa. Sebagai gantinya pelajar dituntut untuk berlatih sacara intensif dalam penggunaan bahasa. Dengan demikian bahasa adalah untuk digunakan, bukan untuk dibicarakan.

4) Setiap bahasa di dunia memiliki kaidah atau aturan masing-masing yang berbeda dengan yang lainnya dan tidak ada gunanya membandingkan atau menyamakan kaidah dari setiap bahasa-bahasa tersebut. ${ }^{26}$

\section{Tarīqah al-TüIifiyyah (Metode Eklektik)}

a. Konsep dan sejarah Thariquah al-Tulifiyah

Metode eklektik adalah metode yang menyajikan bahan pelajaran asing di depan kelas dengan melalui macam-macam kombinasi beberapa metode, 
misalnya: metode langsung, metode gramatika, metode tarjamah dan yang lainnya.

M. Radhi al-Hafid dalam buku Siti Aisyah Chalik mengemukakan bahwa metode eklektik adalah metode yang merupakan kombinasi prinsipprinsip fonetik, intuisi, induksi penggunaan teks modern dan studi gramatika secara sistematis menurut cara tradisional. ${ }^{27}$

Di perancis, metode ini dikenal dengan "methode active". Dalam bahasa Arab, metode ini dikenal dengan tiga nama, yaitu: metode campuran ( الطريقة (الازدو اجية), metode kompromi (الطريقةالوقيفية) dan metode pilihan.

\section{b. Kelebihan dan kekurangan Tariqah al-Tulifiyah}

Sebagaimana yang telah diketahui, tidak ada metode yang terbaik dan terburuk. Menggunakan metode apapun, khususnya dalam pengajaran bahasa asing, di dalamnya akan ada masalah yang harus diatasi termasuk menggunakan metode gabungan ini.

Walaupun terlihat kegiatannya lebih vareatif, kemampuan para pelajar dalam menggunakan bahasa asing dipandang lebih merata, namun menggunakan metode gabungan nampaknya akan bermasalah dengan kesediaan guru dan siswa, dan alokasi baru.

Belum tentu semua guru sanggup melakukan serangkaian kegiatan mengajar yang begitu banyak dan bervariasi. Penggunaan metode ini nampaknya menuntut adanya guru yang segala bisa dan energik. Begitu juga dipihak pelajar. Biasanya kegiatan yang terlalu banyak malah bisa menimbulkan kejenuhan belajar, apalagi jika materi dibawakan secara monoton. Waktu yang diperlukan juga relatif lebih banyak dibandingkan dengan menggunakan metode yang lain, padahal umumnya alokasi waktu pelajaran bahasa Arab di sekolah-sekolah di Indonesia terbatas, kecuali di sekolah-sekolah tertentu yang memberikan perhatian lebih kepada bidang studi bahasa Arab. ${ }^{28}$

\section{METODOLOGI PENELITIAN}

Penelitian ini dilakukan di MANPK MAN 3 Makassar dengan menggunakan jenis penelitian lapangan (field research) dalam bentuk penelitian kualitatif. Pengertian teoretis tentang penelitian kualitatif adalah penelitian yang terbatas pada usaha mengungkapkan suatu masalah dalam keadaan bagaimana adanya, sehingga hanya merupakan penyingkapan fakta. $^{29}$ Adapun pendekatan pada penelitian ini adalah pendekatan pedagogis, yaitu pendekatan yang dilakukan dengan menggunakan teoriteori pendidikan dalam proses pembelajaran yang melatarbelakangi metode pembelajaran bahasa Arab. Sumber data yang digunakan adalah sumber data primer yaitu dengan melakukan wawancara langsung pada pihak-pihak yang berkaitan langsung dengan proses pembelajaran bahasa Arab dengan subjek penelitian pada penelitian ini adalah wakil kepala madrasah, para guru yang mengajarkan bahasa Arab dan siswa-siswi yang mengikuti pembelajaran bahasa Arab di MANPK MAN 3 Makassar. Pengumpulan data dilakukan dengan cara observasi, wawancara dan dokumentasi, Analisis data pada 
penelitian ini menggunakan analisis interaktif yaitu dengan melakukan langkah-langkah seperti: Data Reduction (Reduksi Data), Data Display (Penyajian Data) dan Conclusion Drawing / Verification (Penarikan Kesimpulan / Verifikasi)

\section{HASIL PENELITIAN}

Berdasarkan hasil pengamatan peneliti selama proses pembelajaran dan disesuaikan dengan hasil wawancara dengan para guru bahasa Arab, pembelajaran bahasa Arab di MANPK MAN 3 Makassar dilakukan dalam tiga tempat yaitu formal (di sekolah), asrama dan pengajian yang dilakukan di mesjid. Adapun metode pembelajaran yang digunakan oleh guru pada saat pembelajaran di dalam kelas diantaranya:

\section{Metode ceramah}

Metode ini diajarkan pada saat pembelajaran di dalam kelas, guru menerjemahkan materi dari bahasa Indonesia kedalam bahasa Arab kemudian peserta didik menghafal materi yang telah diterjemahkan ke dalam bahasa Arab. Setelah siswa menghafal guru kemudian menjelaskan materi yang akan dipelajari tersebut

\section{Metode koperatif (pembelajaran berkelompok)}

MANPK MAN 3 Makassar telah menerapkan kurikulum K13 sehingga setiap pendidik diharuskan melakukan proses pembelajaran yang inovatif, hal ini dilakukan guna menghindari kejenuhan yang timbul dalam diri siswa

Adapun pembelajaran yang dilakukan di asrama dan pengajian dimesjid dilakukan diluar jam pelajaran formal yaitu antara jam 16.15-21.30, adapun pelajaran yang diberikan antara lain: Qira'ah wa tarjamah, Nahwu, Hiwar, Tafsir, Hadist, Insya wa ta'bir, imla' wa kitabah dan sharf. Metode yang digunakan adalah sebagai berikut:

1. Metode Qira'ah dan tarjamah

Metode ini diajarkan pada pengajian rutin yang diadakan di asrama MANPK MAN 3 Makassar, adapun kitab yang digunakan pada pengajian ini yaitu kitab ta'lim muta'lim. Guru membaca dan menerjemahkan kemudian siswa-siswi mendengarkan dengan sekasama. Setelah guru telah usai membaca dan menerjemahkan selanjutnya siswa disuruh membaca kitab tersebut secara bergiliran.

\section{Metode Imla' kitabah}

Metode ini diajarkan untuk menunjang kemampuan menulis bahasa Arab siswa MANPK MAN 3 Makassar, kitab yang digunakan adalah kitab Qowa'id al-imla. Adapun langkah yang digunakan adalah guru membaca dan menerjemahkan materi yang akan diajarkan kemudian menjelaskannya. Setelah menjelaskan materi yang telah diajarkan, guru kemudian mendikte materi yang telah dijelaskan sebelumnya, hal ini dilakukan untuk meningkatkan kemampuan menulis Arab siswa MANPK MAN 3 Makassar. 


\section{Metode menghafal}

Metode menghafal dilakukan pada saat mengajar tutor bahasa yang diadakan diasrama siswa, adapun kitab yang digunakan adalah syarah matan jurumiyah (Mukhtashorun Jiddan. Pada pelajaran tutor bahasa siswa disuruh menghapalkan matan dan syarah dari kitab tersebut, kemudian dijelaskan maksudnya. Selain kitab syarah matan jurumiyah, pelajaran yang diajarkan dengan metode ini adalah sharaf dan nahwu

\section{KESIMPULAN}

Berdasarkan beberapa uraian sebelumnya dapat ditarik beberapa kesimpulan yang menjadikan siswa dan siswi sekolah MANPK MAN 3 Makassar mampu tersebar luas diseluruh universitas baik di dalam negri maupun di luar negri dangan mendapatkan beasiswa adalah adanya upaya mendalam yang dilakukan oleh pihak madrasah untuk menunjang kemampuan peserta didiknya yaitu dengan memberikan pembelajaran tambahan yang dilakukan di asrama, selain itu tenaga pengajar di MANPK MAN 3 Makassar sebagian besar adalah alumni dari mesir dan maroko, hal ini menjadi motivasi tersendiri bagi peserta didik dalam proses pembelajaran.

\section{CATATAN AKHIR}

${ }^{1}$ Depatemen Agama RI, Kumpulan Undang-Undang dan Peraturan Pemerintah RI tentang Pendidikan (Jakarta: Depag RI, 2007), h. 5.

${ }^{2}$ White, J.M and Klein, D.M Family Theories: Second Edition (California: Sage Publication inc, 202), h. 19.

${ }^{3}$ Kementrian Agama RI, Al-Qur'an Terjemah dan Tajwid (Jawa Barat: Sygma, 2014), h. 235.

${ }^{4}$ Mustaqim Ilyas (24tahun), Guru Bahasa Arab MANPK MAN 3 Makassar, Wawancara, Makassar, 25 Oktober 2017.

${ }^{5}$ Depatemen Pendidikan Nasional, Kamus Besar Bahasa Indonesia Edisi Keempat (Cet. II; Jakarta: Balai Pustaka), h. 23.

${ }^{6}$ Rusman, Model-Model Pembelajaran; Mengembangkan Profesionalisme Guru, h.134

${ }^{7}$ Hamzah B. Uno, Model-Model Pembelajaran; Menciptakan Proses Belajar Mengajar yang Kreatif dan Efektif(Jakarta: Bumi Aksara, 2009), h. 5.

${ }^{8}$ Muh. Rapi, Pengantar Strategi Pembelajaran (Pendekatan Standar Proses) (Makassar: Alauddin University Press, 2012), h. 19

${ }^{9}$ Abdul Majid, Perencanaan Pembelajaran, Mengembangkan Standar Kompetensi Guru(Cet. IV; Bandung: Remaja Rosdakarya, 2008), h. 15.

${ }^{10}$ Nurkhalisa Latuconsina, Pengelolaan dalam Kelas Pembelajaran (Makassar: Alauddin University Press, 2013), h. 7 
${ }^{11}$ Oemar Hamalik, Kurikulum dan Pembelajaran (Cet. XI; Jakarta: Bumi Aksara, 2011), h. 57.

${ }^{12}$ M. Quraisy Shihab, Membumikan Al-Qur'an; Fungsi dan Peran Wahyu dalam Kehidupan Masyarakat (Cet. 1; Bandung: Mizan, 1997), h. 169.

${ }^{13}$ Azhar Arsyad, Bahasa Arab dan Metode Pengajarannya, Beberapa Pokok Pikiran (Cet.III; Yokyakarta: Pustaka Pelajar, 2010), h.125.

${ }^{14}$ Ismail. Strategi Pembelajaran Agama Islam Berbasis PAIKEM (Semarang: LSIS dan RASAIL Media Group, 2009), h.7.

${ }^{15}$ Sri Utari Subyakto Nababan. Metodologi Pengajaran Bahasa (Cet. I; Jakarta: Gramedia Pustaka Utama, 1993), h. 170

${ }^{16}$ A. W. Munawwir, Kamus al-Munawwir Arab-Indonesia Terlengkap (Cet. I; Yogyakarta Pustaka Progressif,1984), h. 1224

${ }^{17}$ Dep Dik Bud, Kamus Besar Bahasa Indonesia (Cet. I; Jakarta: PT Gramedia Pustaka Utama, 1993), h. 376

${ }^{18}$ HD. Hidayat, Mukhtasar Turūq Tadrīs al Lugah al-'Arabiyyah Li Tullāb al-Madāris wa al Ma'àhid al indūnisiyyah, (Jakarta: 1986), h. 25-26

${ }^{19}$ Ramzi Munir Ba'labaki,. Mu’jam al-Muștalahāt al-Lugawiyyah, Bairut: (Dār al-'Ilm li alMalāyīn, 1990), h. 216

${ }^{20}$ Mahmud Kamil Hasan Al-Naqah. Usus I'dād Mawād Ta'Tim al-'Arabiyyah wa Ta' lifuhā. Qahira: Kuliyah al-Arabiyah, Jami'ah 'Ain Syams: 2010

${ }^{21}$ Tayar Yusuf, Metodologi Pengajaran Agama dan Bahasa Arab (Jakarta: Raja Grafindo Persada, 1995, h. 152.

${ }^{22}$ Acep Herrmawan, Metodologi Pembelajaran Bahasa Arab, h.178

${ }^{23}$ AcepHermawan, MetodologiPembelajaranBahasa Arab, h.193.

${ }^{24}$ Ahmad FuadEffendy,MetodologiPengajaranBahasaArab(Cet.III; Malang:Misykat, 2005),h.41.

${ }^{25}$ Acep Hermawan, Metodologi Pembelajaran Bahasa Arab, h. 185.

${ }^{26}$ Azhar Arsyad, Turūq Tadrīs al-Lugah al-'Arabiyyah, h.46.

${ }^{27}$ Siti Aisyah Chalik, Metode Pembelajaran Bahasa Arab (Makassar: Alauddin University Press, 2014), h. 106.

${ }^{28}$ Acep Hermawan, Metodologi Pembelajaran Bahasa Arab, h. 199.

${ }^{29}$ Hermawan Warsito, Pengantar Metodologi Penelitian (Jakarta: PT. Gramedia Utama, 1997), h.10. 